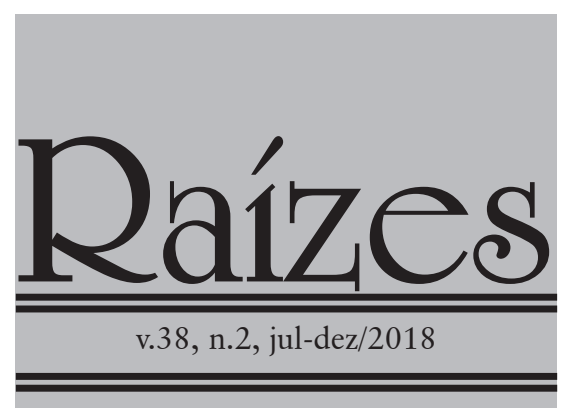

\title{
REPRESENTAÇÕES SOCIAIS SOBRE A EXTENSÃO RURAL NO CONTEXTO DA COMUNIDADE REMANESCENTE DO QUILOMBO NOVA JATOBÁ, CURAÇÁ-BA
}

\author{
Danilo Moreira dos Santos ${ }^{1}$, Nilton de Almeida Araújo ${ }^{2}$ e Helder Ribeiro Freitas ${ }^{3}$
}

\begin{abstract}
RESUMO
Este artigo, fruto da dissertação de mestrado, aborda Representações Sociais de quilombolas e extensionistas acerca da extensão rural e identidade étnica no contexto da Comunidade Remanescente de Quilombo Nova Jatobá, Curaçá-BA. Seguindo uma abordagem qualitativa, tendo como instrumentos a entrevista semiestruturada e a observação, e com base na Teoria das Representações Sociais e na Teoria da Análise de Discurso francesa, apreendem-se as representações de 13 participantes relacionados como usuários, praticantes e espectadores em um contexto de ações de desenvolvimento rural executadas por entidade não governamental. Demonstra-se, acerca dos quilombolas, como a cultura e a identidade influenciam suas representações da realidade. Nota-se uma polissemia nos discursos mobilizados, inclusive com a explicitação de sentidos convergentes entre os dois grupos, que buscam estabelecer primordialmente uma valoração positiva da identidade étnica, da Extensão Rural e da atuação extensionista, porém explicitando sentidos outros a partir do não dito que atravessa o dizível e mesmo dos contrastes presentes no discurso. Representações negativas também se relacionam à significação da realidade, como no caso da identidade quilombola, acerca da qual se explicita uma influência de princípios contrários à noção de "neutralidade racial" nos processos de interação, confrontantes com o próprio sentido de autoafirmação identitária.

Palavras-chave: Representações sociais; Extensão Rural; Comunidades Quilombolas; Identidade Étnica.
\end{abstract}

\section{SOCIAL REPRESENTATIONS ABOUT THE RURAL EXTENSION IN THE CONTEXT OF THE REMAINING COMMUNITY OF QUILOMBO NOVA JATOBÁ, CURAÇÁ-BA}

\begin{abstract}
This article, based on a master's thesis, deals with social representations of quilombolas and extensionists about rural extension and ethnic identity in the context of Quilombo Nova Jatobá, Curaçá-BA. Following a qualitative approach, using as instruments the semi-structured interview and the observation, and based on the Theory of Social Representations and the Theory of French Discourse Analysis, seize-se the representations of 13 related participants as users, practitioners and spectators in the context of rural development actions performed by a nongovernmental entity. It is demonstrated, about the quilombolas, how culture and identity ma-

\footnotetext{
${ }^{1}$ Bacharel em Ciências Sociais e Mestre em Extensão Rural pela Universidade Federal do Vale do São Francisco (Univasf). E-mail: danilo-2010moreira@hotmail.com.

${ }^{2}$ Doutor em História Social. Professor vinculado ao Programa de Pós-Graduação em Extensão Rural (PPGExR/Univasf). E-mail: nilton.almeida@univasf.edu.br.

${ }^{3}$ Doutor em Agronomia. Professor vinculado ao PPGExR/Univasf. E-mail: helder.freitas@univasf.edu.br.
} 
ke up their representations of reality. There is a polysemy in the mobilized discourses, including the explanation of convergent meanings between the two groups, which seek to establish a positive valuation of ethnic identity, Rural Extension and extensionist activity, but expliciting other meanings from the not said that crosses the sayable and even the contrasts present in the discourse. Some negative representations too related to the meaning of reality, as in the case of the quilombola identity, about which an influence of principles contrary to the notion of "racial neutrality" in the processes of interaction is explicited, confronting the very meaning of self-affirmation of identity.

Key words: Social Representations; Rural Extension; Quilombola Communities; Ethnic Identity.

\section{INTRODUÇÃO}

Este artigo, oriundo de dissertação de mestrado, objetiva analisar as representações sociais de quilombolas e extensionistas acerca da Extensão Rural e identidade étnica, na Comunidade Remanescente de Quilombo Nova Jatobá4, Curaçá-BA, buscando uma contextualização de concepções e de sentidos atribuídos aos objetos simbólicos em questão.

A pesquisa teve como principais interlocutores 11 comunitários quilombolas, três do sexo masculino e oito do sexo feminino. Destas ultimas, sete (idades: 25, 31, 31, 28, 38, 45, 54) são caracterizadas como beneficiárias diretas das ações mais recentemente desenvolvidas na comunidade através do Instituto Regional da Pequena Agropecuária Apropriada (IRPAA), o projeto Ecoforte-Redes 5 , ligado ao Programa de Ampliação e Fortalecimento das Redes de Agroecologia e Produção Orgânica (Programa Ecoforte), que integra o Plano Nacional de Agroecologia e Produção Orgânica (Planapo/Brasil Agroecológico), instrumento da Política Nacional de Agroecologia e Produção Orgânica (PNAPO). Os outros quatro participantes quilombolas caracterizam-se como espectadores das referidas ações, sendo três homens e uma mulher (idades: $45,70,73,74)$, cuja seleção observou critérios de geração e gênero, a verificação da história e da memória local e o histórico de liderança junto à Associação Quilombola, sendo três participantes nesta última condição.

Também foram entrevistados dois extensionistas da referida instituição, IRPAA, entidade não governamental sediada no município de Juazeiro-BA e que há sete anos atua na comunidade Nova Jatobá com atividades na linha de Convivência com o Semiárido e Assistência Técnica e Extensão Rural (ATER), entre outras. Ambos os extensionistas, um do sexo masculino (30), outra do sexo feminino (30), foram selecionados segundo a acessibilidade e o grau de envolvimento no projeto, já que nem todos os cinco profissionais relacionados estavam formalmente integrados à equipe quando da abordagem.

Os pressupostos teórico-metodológicos que fundamentam as análises estão assentados principalmente na Teoria das Representações Sociais de Serge Moscovici (2003) e na Teoria da Análise de Discurso francesa, na perspectiva de Eni Orlandi (2005a; 2007).

A pesquisa é aprovada pelo Comitê de Ética em Pesquisa (CEP) da Universidade Federal do Vale do São Francisco (Univasf), parecer no 2.364.724, e CAAE nº 73919017.0.0000.5196, emitido em 04 de novembro de 2017. Observam-se, portanto, as normas éticas de realização de pesquisas com seres humanos. Procedeu-se à subscrição de Carta de Anuência e Termos de

\footnotetext{
${ }^{4}$ Situada no município de Curaçá e na microrregião de Juazeiro, no Norte baiano, a comunidade Nova Jatobá foi certificada pela Fundação Cultural Palmares (FCP) no ano de 2008. Constam em seu registro 212 famílias. Conforme o participante QE11, a comunidade possui uma estimativa de 848 pessoas. Ainda que no ano de 2010 tenha sido aberto processo administrativo numa Superintendência Regional do Instituto Nacional de Colonização e Reforma Agrária (INCRA), até hoje não ocorreu a titulação do território quilombola, o qual integra ao todo sete povoados que mantêm afirmação dessa identidade.

${ }^{5} \mathrm{Na}$ comunidade o projeto Ecoforte tinha como usuárias diretas dez mulheres integrantes da Associação Quilombola, as quais realizavam o beneficiamento de produtos derivados da mandioca, entre outros usuários indiretos.
} 
Consentimento Livre e Esclarecido (TCLE), respeitando-se a privacidade de participação voluntária. $\mathrm{Na}$ abordagem dos dados substituem-se os nomes dos participantes por termos especiais (TE-1 e TE-2: “Técnico Entrevistado"; QE-1... QE-11: "Quilombola Entrevistado”), resguardando sua identidade e privacidade.

O artigo compreende quatro seções, além desta introdução e do item final: 1) a primeira seção traz breve contextualização sobre a Teoria das Representações Sociais; 2) a segunda, uma contextualização sobre a Teoria da Análise de Discurso; 3 ) a terceira, a abordagem das representações dos quilombolas; e 4) a quarta, as representações dos extensionistas, concluindo com as considerações finais.

\section{SOBRE A TEORIA DAS REPRESENTAÇÕES SOCIAIS}

As abordagens pioneiras sobre representações remontam ao Sociólogo francês Émile Durkheim (1858-1917), fundador da sociologia enquanto disciplina acadêmica e criador do conceito de Representações Coletivas. Embasando-se no positivismo das Ciências Sociais, Durkheim (2007) estabeleceu os fatos sociais como "coisas", ou objetos cientificamente observáveis e mensuráveis, e assim definiu o objeto de estudo da Sociologia e seus fundamentos metodológicos. Desse modo, defendeu uma separação entre fatos sociais (representações coletivas), e fatos psíquicos (representações individuais).

Partindo de Durkheim, o conceito de Representações Coletivas é alargado pelo Psicólogo Social romeno (e naturalizado francês) Serge Moscovici, como a Teoria das Representações Sociais (TRS), a partir da tese de doutorado La psicanalyse, son image et son public (1961). Não suplantando as importantes contribuições do Sociólogo, a consolidação da TRS a partir de Moscovici buscou aproximar os estudos da psicologia social aos da sociologia, articulando os aspectos subjetivos e cognitivos do sujeito ao âmbito sociocultural.

Acerca da produção das RS, que está relacionada à necessidade de familiarizar o desconhecido que assusta, são destacados a objetivação (dar vida ao imaginário por meio da familiarização do novo, tornando dada ideia representável a partir de um ícone. Por exemplo, relacionar Deus a um pai), e a ancoragem, que torna familiar o que é estranho, a partir de uma classificação e caracterização baseada em paradigmas categóricos depositados na memória (Moscovici, 2003, p. 61). Portanto, a apreensão das RS é feita com base nesses dois princípios.

Destaca-se, sobre a representação social, que ela "é uma forma de conhecimento, socialmente elaborada e partilhada, (...) e que contribui para a construção de uma realidade comum a um conjunto social." (Jodelet, 2001, p. 22). Segue-se o pensamento precursor, que definira Representações Coletivas como "O conjunto das crenças e dos sentimentos comuns à média dos membros de uma mesma sociedade [...]” (Durkheim, 1999, p. 50).

No processo representacional, sujeito e objeto se constituem em processos de interação e de comunicação. Os sujeitos podem ser relacionados a partir de dado objeto e, ao mesmo tempo, dado sujeito tem sua relação com dado objeto influenciada por outro sujeito (Moscovici, 2003; Jovchelovitch, 2004). Assim, a TRS permite verificar como se dá a produção de saberes (sobre si mesmo, sobre o outro e sobre o próprio contexto de vida) por sujeitos de contextos diversos. Torna-se, portanto, fundamental à proposta que origina este trabalho, pela qual se examinou o modo como se produz e se sustenta um conhecimento compartilhado por sujeitos e grupos relacionados a partir de objetos comuns, como a identidade e a memória social de um grupo étnico, e a execução de ações de desenvolvimento rural em um contexto específico.

A apreensão das Representações Sociais se torna possível a partir de diferentes métodos, sendo um deles a entrevista em conjunto com abordagens teórico-metodológicas como a Aná-

${ }^{4}$ Como também empreendido por Santos (2014) no contexto da Comunidade Remanescente de Quilombo Lage dos Negros, em Campo Formoso-Bahia. 
lise de Discurso ${ }^{6}$. Esta se torna uma ferramenta fundamental para exame das RS, uma vez que elas têm no discurso (e recursos linguísticos inerentes) um importante meio de produção e circulação.

\section{SOBRE A TEORIA DA ANÁLISE DE DISCURSO}

Intercalando três ramos disciplinares, a linguística, o marxismo e a psicanálise, "A Análise de Discurso reúne [...]: a. a teoria da sintaxe e da enunciação; b. a teoria da ideologia e c. a teoria do discurso, que é a determinação histórica dos processos de significação." (Orlandi, 2005 a, p. 25). Assim, na busca pela compreensão dos processos de significação da realidade, ela procura situar o dizer em sua relação com a exterioridade.

Como importante referência na Análise de Discurso destaca-se o filósofo Michel Pêcheux (1938-1983): "Ele é o fundador da Escola Francesa de Análise do Discurso que teoriza como a linguagem é materializada na ideologia e como esta se manifesta na linguagem.” (Orlandi, 2005b, p. 10). Para esse teórico, a apreensão do sentido no funcionamento da linguagem requer um trabalho de "descrição" e "interpretação" das "materialidades discursivas" (Pêcheux, 1990, p. 50). Complementando-o, Orlandi (2005a) discute que a compreensão a partir de uma "explicitação" também é fundamental para a abordagem da constituição dos significados no discurso.

A AD transcende as palavras faladas ou escritas. Busca apreender não o significado de determinado texto, mas o processo pelo qual significa. Por isso, ela está atenta às condições de produção do discurso, que envolvem, segundo Orlandi (2005a, p. 30), o sujeito, a situação, a memória e o contexto sócio histórico e ideológico de produção do discurso.

A Teoria do Discurso envolve conceitos fundamentais, como: formação discursiva, formação ideológica, enunciado, interdiscurso, interdiscursividade, etc. Sobre os dois primeiros conceitos: "A formação discursiva se define como aquilo que numa formação ideológica dada - ou seja, a partir de uma posição dada em uma conjuntura sócio-histórica dada - determina o que pode e deve ser dito." (Orlandi, 2005a, p. 43). Ainda sobre formação discursiva, são grupos de enunciados definíveis a partir de uma determinada regularidade, de modo que "Um enunciado pertence a uma formação discursiva, como uma frase pertence a um texto [...].” (Foucault, 2008, p. 132).

Quanto ao discurso, seria algo que decorre do mesmo "sistema de formação" como o "do discurso clínico, do discurso econômico, do discurso da história natural, do discurso psiquiátrico.” (Foucault, 2008, p. 122).

As noções de interdiscurso e interdiscursividade pressupõem redes de memória pelas quais todo discurso remete a um discurso-outro, de modo que o sujeito não se constitui autor soberano do seu discurso. Pela historicidade, ele é anterior aos sujeitos, mas é mobilizado (e por vezes reformulado) no contexto das interações sociais e relações dialógicas operantes. É através de uma circulação por meio da linguagem que o discurso (re)estabiliza-se, a partir de consensos alcançados mediante disputas de sentido pelas quais se busca a significação da realidade.

\section{REPRESENTAÇÕES SOCIAIS DOS QUILOMBOLAS SOBRE EXTENSÃO RURAL E IDENTIDADE ÉTNICA}

Trata-se aqui de um grupo de identidade étnico-racial autodefendia, a partir da qual o próprio sujeito tende a buscar se afirmar enquanto ser social e assim definir sua posição em 
campo. Todos os comunitários entrevistados afirmam uma identidade quilombola, o que para a maioria ocorre em paralelo ao sentido de afirmação da própria identidade negra, em expressão de um "orgulho de ser negro e ser quilombola!" (QE-11). Nesse aspecto, como expôs o participante QE-8: “Quando [...] eu nasci mesmo... os meus pai e... meus avô, eles já falava nessa origem. [...] o pessoal da cidade dali de Curaçá [...] gostava muito do pessoal daqui. O pessoal chamava os neguim de Jatobá, porque era nêgo mesmo! Mais a gente se sentia feliz porque era a origem da gente. Era o sangue da gente.”

Conforme explicitado a partir de processos enunciativos dos onze quilombolas entrevistados, a luta por direitos ("Lutar pelos seus direito!” QE-1; "Ser quilombola é [...] lutar pelo seu objetivo.” QE-4), o resgate e valorização das origens e da cultura e a afirmação da identidade ("pra mim é tudo! Se eu nasci já meus pai já se considerava quilombola, eu num posso mudá a minha origem." QE-8; "Ser quilombola é a nossa origem! Se somos quilombola tem mais que aceitar!” QE-3; "Porque [...] foi passano pra gente sobre os mais véio, que já... tratava tudo assim [...].” QE-7), e também a união (“[...] sê quilombola... é [...] ser unido uns com os outros, pra ver se consegue uma vida melhó.” QE-9; “Ser quilombola [...] é você viver, né, no meio do seu povo, é você ter união uns com os outros, pra se organizar, é dar apoio uns aos outros [...].” QE-11; “[...] a gente tem que aconselhá uns aos outro e permanecer a união e o trabaio, como a gente fazia, e em comunidade, que a gente só trabaiava em mutirão.” QE-8), são alguns dos objetos sociais que os mesmos acionam enquanto ancoradouro das representações da própria identidade étnica.

Os enunciados analisados explicitam ancoragens e objetivações de elementos que em certa medida corroboram categorias verificadas por Santos e Chaves (2007, p. 359), quantificadas como: "Ser quilombola é pertencer a uma comunidade negra, assumir sua cor, sentir orgulho (50\%), lutar contra o racismo, pela liberdade, pelos ideais, pelos objetivos (20\%). [...] Ser quilombola é ter a 'consciência limpa' (10\%), isto é, sem preconceito.”.

Parafrasicamente, alguns enunciados se amparam em referências históricas e simbólicas, acionadas em meio à memória coletiva para representação do que é ser quilombola. Memora-se, assim, o ícone da resistência e luta negras, Zumbi dos Palmares, referência fundamental no processo de afirmação identitária de povos quilombolas e comunidades negras engajadas: “É não se renegar! Que nem Zumbi lutou, né? Zumbi dos Palmares lutou muito pela liberdade. E é isso que a gente quer, lutar para conseguir nossos objetivos" (QE-2); "Ser quilombola é [...] você viver, né, aquilo que, de fato, é dos teus antepassados. [...] Até porque nós pra chegar onde chegamos hoje teve alguém que morreu por isso, teve alguém que deu a vida pra que nós pudesse hoje ter uma melhoria da qualidade de vida.” (QE-11). Explicita-se, nessa formação discursiva da valorização identitária, o amparo no discurso histórico para representação, explicação e significação da realidade, o que se processa mediante incorporações e atualizações de uma memória quilombola afro-brasileira compartilhada.

Também por meio do discurso histórico, em alguns enunciados os sentidos explicitados funcionam pela ancoragem das representações sociais sobre quilombo enquanto modo de resistência ao sistema escravista (como: “[...] é... um meio da gente saí da escravidão, e... torná as coisa mais fácil [para] nóis.” QE-6; "se livrar [...] daquilo que trazia o [...] sofrimento do negro. [...] os negros fugia daquela situação que eles vivia e lá nos quilombo apoiava ele” QE-11), ou remontam à memória da comunidade, tendo como ponto de filiação de sentidos a tradição transmitida pelos mais antigos e a preservação da história identitária pela memória e o discurso dos mesmos, como: "por causa do tempo mais véio, a união dos mais véio [...]. Aí mermo os mais véio disse que aqui tem umas pessoa que considera assim [...]” (QE-7).

Conforme verificado em muitos enunciados convergentes, como no exposto a seguir, o sentido de união é mobilizado e atravessa, junto a outros sentidos, como o de coletividade 
no trabalho, as representações sobre quilombo, o que pode, ou não, receber alguma influência também da percepção de uma importância externa conferida a formas de participação coletiva, como o sistema de mutirão.

[...] a gente tem que aconselhá uns aos outro e permanecer a união e o trabaio, como a gente fazia, e em comunidade, que a gente só trabaiava em mutirão. Você vê uma obra dessa aqui [referindo-se ao prédio da associação], nóis fizemo nosso suó, [com] nossos braço. Nós cavava o barro, amassava o barro, fizemo o tijolo, nós queimava o tijolo! Nóis foi quem levantamo. [...] por isso que a gente se sente feliz, até hoje a gente se valoriza bem porque nóis tem que mantê a nossa cultura. Porque se nóis somo quilombola... nóis temo que nos dá valô, que se nóis não se dé valô os outro não vão dá. (QE-8).

As filiações ao sentido de união são ainda empreendidas em relação aos demais objetos, a exemplo da própria Extensão Rural, como será demonstrado mais adiante.

Mesmo que no processo de enunciação se julgue desinformado sobre o aspecto identitário, um dos sujeitos formula a representação de algo que tem um caráter positivo e que pode trazer benefícios aos que aderem: "Rapais, no momento eu ainda tô disinformado com isso, mais tô chegando. [...] sei que disse que é um órgum bom, quilombola. [...] o pessoal tá incachano nisso pra vê se dá certo alguma coisa.” (QE-9).

Com enunciados inscritos numa formação discursiva de discurso fatalístico e de vulnerabilidade socioeconômica quilombola (“Óia, quilombo eu acho que é [...] uma famía que nasceu ali muito pobre, muito dependente, véio! Muito sufrida como a gente vê, é... aqui do pessoal, [...]. Que a gente sofreu muito pra... sobrevivê. Nós trabalhava [...] cedinho, pegava só largava a boca da noite." QE-8), associa-se as dificuldades de sobrevivência dos quilombolas à pobreza socioeconômica, destacando o trabalho e o esforço empreendido através do mesmo como alternativas prementes. Esse discurso fatalístico e ao mesmo tempo econômico explicita o efeito de sentido da disposição de quilombolas a um estado de vulnerabilidade, sujeição e carência, explicitando a necessidade histórica de maior atenção a esses povos. Aqui funciona efeito parafrásico de discursos cujas significações a se estabelecerem ganham forma, igualmente, no discurso acadêmico-científico, que fornece versões similares dessa mesma realidade, denunciando a negligência referente à situação desses povos, como no exemplo a seguir:

Os territórios quilombolas, a maioria situados em regiões rurais, ainda permanecem esquecidos e muitos se encontram em situação de vulnerabilidade social, vivendo apenas de uma agricultura de subsistência e/ou com bolsas de crédito que o governo federal oferece, em alguns casos. Graças a essa característica "rural" das comunidades remanescentes de quilombo, uma das estratégias para a promoção do desenvolvimento local dessas comunidades, tem se dado através da agricultura. (Mendes, 2014, p. 14).

Com efeito, além do impacto no plano das relações raciais, também uma negligência histórica quanto ao acesso a recursos e serviços fundamentais é característica da realidade quilombola, conservando muitos povos na linha da pobreza. Por isso mesmo, nos últimos anos tem havido, ante a mobilização por direitos e por reconhecimento, o investimento em programas e ações de caráter paliativo ou ações estruturantes visando aplacar desigualdades sociais e econômicas a que muitos grupos quilombolas estão tradicionalmente submetidos, como é o caso do Programa Brasil Quilombola.

Ante esse contexto, a própria admissão da identidade quilombola simboliza uma oportunidade para muitas comunidades negras rurais. É representada como uma possibilidade de 
viabilização de benefícios ("torná as coisa mais fácil” QE-6), uma fresta de oportunidade ("pra adquirí acho que as coisa, [...] existí as coisa nas comunidade... ter aquele disinvulvimento pras pessoa trabalhá" QE-10). De sua leitura de mundo, porém referenciadas pela memória do dizível, essas duas mulheres quilombolas entendem que a assunção e afirmação da identidade étnica oportuniza um reposicionamento ante as ações governamentais, sendo uma forma de poder intervir nas condições locais.

O atravessamento de sentidos constitutivo do dizível também influencia a mobilização da categoria trabalho na objetivação de diferentes objetos, a exemplo do quilombo (enunciado como algo "[...] que monta os grupo [...] pra trabalhá, pra ter o trabalho e existí as coisa nas comunidade..." QE-10) e também da Extensão Rural, para a qual o sentido do trabalho é atribuído de maneira indireta e atravessada por outros sentidos, como o de permanência na comunidade ("a extensão rural é justamente isso, é pra que [...] as pessoas possa ter condições de sobreviver lá na sua terra" QE-11), ou também atravessada por um sentido de aquisição de informação para a autonomia ("Porque tem muita gente que num tem como crescê, porque ele num tem uma viabilidade, uma informação de crescê, de vivê, de sabê trabalhá" QE-8), entre outros.

De maneira direta, a categoria trabalho é ainda relacionada a outro significante também frequente nos discursos sobre os objetos propostos, a união para o trabalho: "Extensão Rural? Trabalhar junto! Acho que pra mim é isso, trabalhar junto, sê unido!” (QE-5); “[...] a pessoa trabalhar junto, assim... trabalhar junto, ter união com... as pessoa do grupo, com a associação" (QE-7); "Acho que deve ser um tipo de organização, não?, de trabalho, assim, pra se unir, pra se organizar, pra pudê trabalhar." (QE-10).

Como se nota, com aspectos um tanto convergentes com aqueles verificados por Santos (2014) e Santos e Almeida (2014), que observaram uma associação da Extensão Rural com o trabalho, a partir do presente estudo verifica-se que aquela passa a ser representada em alguns discursos como processos de orientação a um aspecto prático da vida dos sujeitos, a sua reprodução material, fazendo-se isso a partir da objetivação de elementos atitudinais (coletividade, união e associação) cujo fim último seria o trabalho, um fim prático.

E isso é ainda reatravessado pelo sentido caracterizando a partir de um discurso econômico, que ancora a Extensão Rural enquanto ação interventora que também possui como finalidade a reprodução material e a garantia de sobrevivência no meio rural ("a extensão rural é justamente isso, é pra que você possa fazer um trabalho onde as pessoas possa ter condições de sobreviver lá na sua terra, lá no meio de sua família, lá na, na sua comunidade” QE-11), sem prejuízo de outros efeitos de sentido relacionados à característica polissêmica do discurso neste mesmo enunciado, como será retomado.

Outro enunciado sobre a Extensão Rural, atravessado por um discurso econômico, vê no acesso a ações e à informação um fim prático que também se volta ao trabalho, em cujo alcance de melhor desempenho requer o acesso a ações e à informação para desenvolver-se operacionalmente e economicamente: "Quando você tem [...] aqueles projeto que... vem [...] pra pudê o pessoal crescê. [...] uma informação de crescê, de vivê, de sabê trabalhá. [...] Porque [...] num é você só trabalhá com os braço. Você tem que tê uma mente, uma cabeça boa pra que você trabalhe mais pôco e você tenha mais lucro [...]." (QE-8). Como expressões do interdiscurso, esse sujeito mobiliza inclusive categorias alinhadas ao discurso acadêmico ("tem que deixá aquela economia [...], aquele capital de giro. [...] Você tem quem mantê um projeto, você tem que tê um capital de giro. Você emprega numa mercadoria, você tem que deixá uma coisa do retorno." QE-8), demonstrando como (re)constitui elementos de outros universos enquanto significantes e associáveis à realidade, categorias explicativas que traduzem sua visão do objeto enquanto modo de trabalho e produção socioeconômica. 
Noutro enunciado produzido por jovem usuária das ações mais recentemente desenvolvidas na comunidade, depreende-se o sentido de um auxílio oriundo de instituição e de agente a ela vinculado, orientado à transmissão de conhecimento: "Extensão rural, pra mim, é onde tem um órgão e aí tem a extensão né... vai um técnico pra dar assistência. [...] É, tipo, tem uma escola, aí tem: 'vamo alugar uma sala!', ali é extensão. Eu entendo por isso. Até aí eu acho que é isso." (QE-2, 25). Essa locutora objetiva uma ação do outro, responsável por ir e fazer acontecer. Filiando-se a um discurso tecnicista, com enunciação inscrita numa formação discursiva da intervenção assistencialista, situa as ações no plano da assistência técnica sem incluir-se de maneira participativa no processo. Da mesma forma, ao mobilizar as imagens “escola" e "sala", explicita relações de ensino-aprendizagem que constituem a Extensão Rural a partir de uma mesma relação problematizada pelo discurso acadêmico-científico, quando entendida em seu sentido difusionista em que apenas o profissional se insere como detentor de saber, enquanto seus interlocutores seriam objeto de difusão de processos e técnicas de uma maneira desvinculada da própria visão de mundo e experiência sociocultural, como discute, por exemplo, Paulo Freire (1983).

Esse aspecto é inclusive abordado em fala contrastante, produzida por quilombola do sexo masculino e detentor de experiência representativa local, em cujo enunciado destacado defende a importância de uma atuação intensa do extensionista: “[...] uma visita técnica ela requer que [...] você veja o que as pessoa tão fazendo, [...] assistência técnica que você chega e vai pruma sala, como se você tivesse numa sala de aula, orientano as pessoas no como ela deve fazer, eu não acredito muito nisso!" (QE-11). O fragmento discursivo desse enunciado será abordado em sua completude mais adiante.

Com exceção de dois locutores, a quase totalidade dos quilombolas participantes expressa uma perspectiva otimista sobre o julgamento formulado pelos extensionistas acerca deles. Ancora em suas representações o sentido de uma visão positiva dos extensionistas em relação aos sujeitos quilombolas e àquelas que estão na condição de usuárias das ações executadas. Assim, estabelecem também um sentido positivo sobre si mesmos (o de pessoas capazes e determinadas) a partir de enunciados como: "Eu acho que ele acha que nós somos umas pessoas muito competentes, porque se ele achasse que a gente não era competente, ele não vinha até nóis, trazendo recurso pra gente [...]." (QE-1); "Eu acho que eles acredita, que vê a força de vontade da gente, de tá sempre lutando. Eles tá sempre orientando a gente, buscando o melhor." (QE-4); "Rapaz, eu acho que eles vê força de vontade da gente, [...] tão sempre vino onde tá a gente, ensinano o que a gente não sabe, dano assistência...”. (QE-5).

Apesar da recorrência de uma valoração positiva pela maioria, algumas enunciações expressam representações contrastantes, como aquela na qual se ancora uma ideia de pouco envolvimento das pessoas (“[...] sabe o que que eles veem? Que o interesse é pôco! Participação do pessoal da comunidade... é pôco o interesse.” QE-10), e aquela que relativiza a apreensão das representações do "outro":

Isso é relativo, né, porque nós temos algumas pessoas que de fato vê [...] nóis como... umas pessoas que têm futuro, que pode ter condições de sobreviver, mas tem muitas pessoas que muitas vezes olha a gente como se a gente fosse preguiçoso, como se a gente é só pra receber recursos do governo, que o governo tá investino nas pessoas errada, que a gente não quer nada, que... investir em área quilombola e indígena é perda de tempo, porque são um monte de desinteressado e preguiçoso! [...] algumas pessoas [...] têm uma visão diferente, acha que [...] se fizer um trabalho com essas pessoas isso pode trazer alguns benefícios e até mesmo a questão da melhoria de vida dessas pessoas [...]. (QE-11). 
Observando-se os aspectos de construção das representações sociais da identidade, que envolvem os âmbitos pessoal e social, é bastante expressiva esta enunciação de QE-11, na qual explicita uma apropriação subjetiva da identidade e, ao mesmo tempo, da realidade social, também compartilhada por agentes que adentram a comunidade na condição de executores de ações e projetos, evidenciando a marginalização que ainda persiste em relação a segmentos negligenciados no processo de constituição de uma sociedade nacional. Com efeito, as características étnico-raciais dos grupos indígenas e quilombolas, somadas às condições sociais e econômicas inerentes a um contexto de negação pelo Estado e pela própria sociedade, fixam-se como parâmetros para a sua classificação, no discurso dos "outros”, como sujeitos incapazes: indolentes ("preguiçosos”), acomodados e displicentes ("não quer nada”, “desinteressados”), dependentes (“como se a gente é só pra receber recursos do governo") 7 , sofrendo estes ainda com processos discriminatórios que se orientam a partir de uma noção, historicamente arraigada, de inferioridade frente a outros grupos sociais: "Então isso é relativo, vai de pessoas! Mas tem muita gente que tem uma discriminação muito grande, ainda, com a questão do negro e do índio." (QE-11). Esses fatores relacionados ao universo representacional do qual partilham os quilombolas tendem a influenciar o processo de assunção da própria identidade, como se especifica a seguir.

Nesse aspecto da constituição da identidade pessoal a partir do relacionamento com o "outro", embora a identidade étnico-racial seja por vezes elemento de orgulho para alguns, quando ancoradas representações positivas em meio à interação e comunicação, outros podem filiar-se a efeitos de sentidos opostos, ancorando uma visão negativa de si mesmo e da própria identidade étnico-racial, como se pode analisar a partir das explicitações orientadas pelo fragmento discursivo seguinte. Além disso, examina-se a partir do mesmo como esse povo depara-se com tratamentos discriminatórios também presentes no processo de interação com sujeitos do entorno, evidentemente agentes de instituições públicas do município inclinados a empreenderem atitudes de discriminação institucional, estas que também influenciam o processo de (des/re)estabilização das representações sociais da identidade:

[...] já tivemos algumas pessoas que usou até de racismo, discriminação, é... [...] de achar que o negro não vai a lugar nenhum, que não adianta fazer investimento nele [...]. [...] muitas vezes a gente vê algumas pessoas [...] discriminando: "Há porque esse povo são cheio de direito, só quer ter direito, são, são...", porque muitas vezes quando a gente exige assim nos, nos locais, nos órgãos público, que [...] seja reconhecido... por exemplo, nós tivemos aqui exemplo [...] de alguns posto de saúde aqui, que o nosso pessoal queria que botasse lá na ficha dele como quilombola e as pessoas recusaram a colocar, não queriam colocar. A gente teve que travar uma luta, uma briga, e aí, por isso... e outras coisas também, teve uma pessoa que disse assim: "Esse povo do Jatobá só porque são quilombola agora acha que eles têm direito em tudo!”, né. Então, é uma, uma forma de discriminação de você muitas vezes... e teve algum... até alguns termos mais, é... agressivo no sentido de... discriminação mermo, né. E nosso povo mermo, alguns do nosso povo lá dento da comunidade também, eu acho que em consequência disso, né, eles tiveram até vergonha, muitas vezes, de se assumir como negro. Porque já teve algumas pessoa que: "Você é do Jatobá, você é negro?" - "Sou do Jatobá, mas não sou negro!", né, teve algum... mais, graças a Deus [...] a maioria das pessoas tanto daqui da comunidade, ô aqui da, do povo de Curaçá, quanto das pessoas que vêm trabalhá lá, até mermo que esses

\footnotetext{
${ }^{7}$ Destaca-se, porém, que o sujeito não generaliza o tratamento expresso para todo agente de desenvolvimento que se relacione com a comunidade: “[...] muitos dos técnicos [...] vão no intuito de [...] nos fortalecer e levantar nossa auto estima, no sentido de achar que o que o governo tá fazeno é uma forma de reparar os danos, né, que causaram aos nossos antepassados [...]. Alguns técnico vê isso, [...] mas sempre tem um ou outro que às vezes ainda tem essa visão negativa do nosso povo.” (QE-11).
} 
técnico a maioria deles são profissional, né, então... como eu tô dizendo, sempre tem uma... um ou outro que faz isso, usa esses termo, mais a maioria, graças a Deus, tem nos dado apoio, nos fortalecido. (QE-11).

Analisa-se, portanto, como as representações em confronto na sociedade podem influenciar a própria representação do “eu”, podendo incutir atitudes de afirmação ou de negação da própria identidade étnico-racial, o que neste último caso assume um sentido de autoproteção contra o próprio racismo já tão recorrente na sociedade, ainda que por vezes negado a partir de uma idealização de uma noção de "neutralidade racial".

A valoração positiva acerca da atuação dos agentes executores, enquanto representação expressa pela maioria dos participantes quilombolas, sobretudo as usuárias (como: "Pra mim tá muito bom, [...] porque sempre eles tão trazendo as experiências pra gente, sempre buscando o melhor..." QE-1); "Pra mim tá bem, tão sempre orientando a gente, buscando o melhor" QE-3; “[...] eu acho que eles faz um bom trabalho, que tá incentivano a gente a fazê as coisa, o que a gente não sabe eles ensinam [...].” QE-6), figura como versões partilhadas da realidade ${ }^{8}$ e que se estabelecem como mais aceitas dentro das condições dadas, mas que não excluem outras possíveis verões, a serem formuladas por outros sujeitos e em outras condições de produção. A própria noção de antecipação, que nesse caso pode ser atribuída à posição do conjunto das beneficiárias a partir da Análise de Discurso (Orlandi, 2005a), permite avaliar uma produção de sentidos que leva em conta a visão que possuem acerca do sentido que o outro dará a esse mesmo discurso que se formula. Dessa forma, as explicitações empreendidas não são absolutas, permanecendo outros sentidos que, antonimicamente, inscrevem-se no plano dos conteúdos silenciados ou negados, mas que também perpassam essa formação discursiva.

Como se verifica a partir dessas informações, por influência da antecipação empreendida por maioria dos locutores em meio a um contexto de dependência de ações institucionais em que se acham inscritos, pela qual podem irromper atitudes de silenciamento (Orlandi, 2007), muitos enunciados imprimem versões da realidade que sejam mais aceitas, ancorando, portanto, sentidos de uma valoração positiva a partir do dito sobre a qualidade da ação extensionista, embora também se evidencie uma ausência de assistência quanto ao uso de equipamentos no âmbito do projeto Ecoforte ("Eu acho que o que eles pode fazê quando eles vêm eles passa pra gente, né, [...] só precisano deles, de vir dar uma força com as máquina, que a gente recebemo e a gente não temo frente de mexer com elas ainda.” QE-5), permanecendo silenciados, quanto aos outros, os sentidos do não dito ou do que é negado.

Outros discursos são proferidos por sujeitos que não dependem diretamente de ações e projetos de desenvolvimento executados na comunidade, como o próprio projeto Ecoforte, que assistiu a um grupo restrito de mulheres. Nesse caso, podem trazer em seus pontos de ancoragem elementos outros, tendendo a sentidos mais prescritivos (como: "[...] eles deve vê com... encará como aprendizado, né... fortalecer, orientá as pessoas e dá muita coragem, porque sem a coragem, sem a força de vontade num vai, né.” QE-8; "Rapaz, pra melhorá tem que... eles vim, atendê tudo direitinho, conversá tudo numa boa, tudo unido, né, que a união faz a força [...].” QE-9), ou ainda sentidos explicitados por avaliação ainda mais enfática dessa relação que compreende a postura dos assistidos, a atuação extensionista em geral e seu contraste com a realidade da comunidade:

${ }^{8}$ Conforme Jodelet (2001, p. 32), “as representações instauram versões da realidade, comuns e partilhadas.”, as quais, segundo a autora, podem ser explicadas a partir de fenômenos da comunicação, aliados à influência da palavra e dos discursos. 
Eu acho que o papel do técnico, é o seguinte: eu nunca fui a favor [...] de algumas visitas técnica no sentido de você chegar lá e você fazer uma visita à comunidade e ir embora, passar uma, duas horas. [...] uma visita técnica ela requer que você vá à comunidade, você veja o que as pessoa tão fazendo, vá lá na roça, vá lá no trabalho que ele faz pra que você possa é... ver como é o trabalho dele. [...] assistência técnica que você chega e vai pruma sala, como se você tivesse numa sala de aula, orientano as pessoas no como ela deve fazer, eu não acredito muito nisso! [...] a melhor assistência técnica é você dar assistência técnica fazendo junto com o produtor. [...] Por exemplo, um projeto desse que tá aí, [...] não basta só você pegar um material desse, capacitar essas pessoas e agora entregou as máquina e jogá elas lá pra trabalhar. Eu acho que agora é que nós devemos acompanhar pra que isso dê certo. [...] porque nós precisamos mudar, porque tantos recursos já foi jogado aí pra o governo em muitos projeto e não deu certo. Eu acho que o que falta dentro das política pública, dentro dos projeto do governo, das instituições, é justamente isso: “Ó, vamo pegá aqui uma região, vamo capacitar esse povo, vamo dá condições dele trabalhar pra ele sobreviver. Agora nós vamo dá codições" - aquilo que... ditado que diz: "Em vez de você dá o peixe, dê o anzol pra ele pescá!" - "Então vamo dá o anzol aqui, vamo ensinar ele pescá, vamo capacitar ele, vamo acompanhar. Agora é o seguinte, companheiro, você tem tudo pra você sobreviver. Se você não fizer por onde sobreviver, isso é questão sua. $\mathrm{O}$ governo nem mais ninguém tem nada a ver! Agora nós vamos trabalhar com outras pessoas que ainda não receberam o que vocês já receberam [...]!”. Então eu acho que deve ser assim. Os projetos, as assistência técnica deve ser isso. É um ano? É dois ano? É cinco ano, se for necessário? Então que seja! Mas saiu dali, deixou aquela comunidade caminhano com suas próprias perna! [...] porque senão nós vamos viver o resto da vida só na dependência do governo [...]. (QE-11).

Nesta enunciação, o discurso responsabilizador se desprende momentaneamente do sentido de valorização positiva do trabalho extensionista e, além de chamar a atenção para o papel do assistido no processo de consolidação da transformação de sua própria realidade, busca, sobretudo, questionar a execução das ações, objetivando a necessidade de se romper com práticas meramente assistencialistas que não resolvem questões estruturantes. Fixa essa representação inclusive por meio da estabilização de sentidos conotativos a partir da ancoragem de imagens mentais com base em ditado metafórico popularmente conhecido e que orienta substituir atitude assistencialista (“dar o peixe”) por ação educativa (“ensinar a pescar”) para, assim, propiciar a autonomia. Objetiva, portanto, a necessidade de maior presença e envolvimento dos extensionistas enquanto forma de incentivo à emancipação, sentido silenciado em outros discursos, quando não dito ou negado.

Este enunciado acima exposto explicita sentidos sobre uma realidade em muito abordada pela literatura científica e pela qual já foram apontadas possíveis limitações do atual modelo de ATER relacionadas às suas condições de execução. A este respeito, propõe-se, por exemplo, que a determinação de metodologias participativas pela PNATER em paralelo a contratos com períodos limitados ${ }^{9}$ e com atividades a serem rapidamente executadas pelos técnicos inviabilizaria o seu próprio estabelecimento, por estas condições de tempo reduzido não serem favoráveis às mesmas (Caporal, 2011, p. 28).

\footnotetext{
${ }^{9}$ Em Nova Jatobá as ações possuem esse caráter temporário, como as do próprio projeto Ecoforte, que durou dois anos. Contudo, há o desenvolvendo de ações sucessivas na comunidade, o que, por outro lado, pode ter outras implicações, já que, como também questionou Caporal (2011), a concentração em um mesmo lugar pode excluir outros necessitados de intervenção. Outra questão é a verificação da permuta de técnicos, o que impacta o encadeamento das ações, podendo implicar no desconhecimento quanto a aspectos da realidade concreta do grupo atendido. A sobrecarga, pelo envolvimento em diferentes ações e comunidades, também pode ocorrer, dificultando a consolidação de princípios atualmente defensáveis à Extensão Rural.
} 
Outros enunciados se tecem como formas avaliativas da ação extensionista, passando a explicitar sentidos outrora silenciados, trazendo como ponto de ancoragem não mais uma valoração positiva do lugar do outro enquanto executor das ações, mas a percepção da necessidade (e mesmo prescrição) de uma maior presença quanto ao processo de orientação e de apoio e em relação à estruturação de um local de trabalho mais adequado e que ofereça melhores condições à atuação das assistidas e ao sucesso do empreendimento: "Tem que ter uma estrutura mais adequada”, “Tem que tá sempre ali pa tá orientano” (QE-8); "O que eles poderia fazê era vim mais assim na gente, porque nóis ainda não sabemos, é... mexer nas máquinas e eles poderiam vim aqui ensiná nóis pra nóis aprendê a trabalhá mais.” (QE-6).

Permanecem, quanto à fixação de sentido sobre como a instituição IRPAA deveria atuar, determinações da posição discursiva assumida a partir do lugar do sujeito locutor, com a mesma tendência de valoração positiva da atuação institucional por parte daquelas dispostas na condição de usuárias diretas das últimas ações desenvolvidas (como: "Eu acho que do jeito que eles já tão vindo, que quando eles têm um projeto eles traz pra comunidade aí as pessoas dá a opinião, e tá sempre ali orientano, buscano o melhor." QE-3; "Eu acho que o que eles pode fazê por a gente eles tão fazeno. [...] Porque quando tem as coisa pra eles vim ensiná a gente eles vêm [...]" QE-5), ainda que haja um tensionamento para sentidos outros em enunciado correlato: "Eu acho que o que eles pode fazê quando eles vêm eles passa pra gente, né, [...] só precisano deles, de vir dar uma força com as máquina, que a gente recebemo e a gente não temo frente de mexer com elas ainda. Mas quando eles vêm são atencioso, explica tudo direito.” (QE-4).

Em alguns momentos, fatos outrora silenciados passam a ser enunciados, permitindo que se estabeleça uma avaliação mais diversa, expressando o anseio por apoio quanto a uma estrutura própria para trabalhar e ainda o apoio na conexão com canais de comercialização dos produtos: "Poderia ajudá a gente a... construir nosso [...] local de trabalho, porque aqui é emprestado, e... pode procurá também é... alguns comércios pra vê se tem como pegá nossa mercadoria pra levá pra nóis vendê...” (QE-5). Convergentemente, outra participante do grupo das usuárias também passa a objetivar a necessidade de um maior apoio em questões estruturantes, explicitando o anseio por um local próprio e mais adequado para se trabalhar:

É... [...] como a instituição deveria ajudá a gente é nisso: um local pra gente podê trabalhá... porque aqui é muito apertado. E... se quando a gente começá fazer [...] uma encomenda grande, não tem como trabalhá aqui porque aqui é a sede da associação que é pra várias coisa. Então a gente ter um lugá adequado pra gente podê trabalhá sossegado! (QE-6).

Nesse aspecto da atuação institucional, embora o sujeito QE-11 averbe uma situação acerca da qual identifica uma necessidade de mudança (“[...] ele dá uma assistência maió ao pessoal lá do centro da caatinga. Mas pra mim o IRPAA deveria atuar no município de Curaçá como um todo"), como expressão dos efeitos de polissemia, reforça, noutra enunciação, uma visão positiva sobre a entidade executora:

[...] O IRPAA tem dado uma atenção especial aqui pra os produtores, né. [...] é a única instituição no sentido de apoiar tanto na área produtiva, quanto na área [...] do sequeiro, [...] apoiado muito bem. E cada projeto que o IRPAA elabora junto com [...] outras instituições, isso só tem a... engradecer a comunidade que são contemplada com isso. [...] trazer benefício. Agora é aquela questão que eu sempre digo ao pessoal: o IRPAA, [...] o governo ou qualquer outra instituição tá fazeno a parte dele no intuito de trazer a melhoria das qualidade de 
vida. Agora depende muito também da comunidade e dos grupos desempenhar sua função e cumprir com sua parte. (QE-11).

O enunciado acima exposto, que explicita sentidos atravessados pela influência de um histórico do exercício de liderança do enunciador, converge para a significação da própria posição discursiva assumida, orientada ao dever de desempenhar papeis de sensibilização e mobilização dos atendidos, para além do aparente apreço pelo projeto e pela ação dos executores. Procede, novamente, à mesma função de discurso responsabilizador, mas desta vez o fluxo discursivo desloca o sentido da responsabilidade institucional, outrora enunciada pelo mesmo sujeito, para a responsabilidade dos sujeitos assistidos nas ações em geral e no projeto Ecoforte em particular, encarregando-se de recomendações que lhes atribuem (e que cobram) um sentido de agência quanto à assunção de papeis coletivos e individuais necessários ao êxito das ações. Transferindo a responsabilidade para outro extremo dentre aqueles envolvidos no processo, o locutor circunscreve e limita a ação institucional e governamental à ação de "trazer benefício", "trazer a melhoria" (viabilização de projetos e recursos e fornecimento de equipamentos, etc.), atribuindo, agora, a responsabilidade pelo êxito dos projetos aos seus usuários, no caso do Ecoforte, às usuárias. Verifica-se, desse modo, o tensionamento ideológico performático dos sentidos atribuídos pelo agente envolvido no processo de constituição do projeto de desenvolvimento rural.

Ainda que em algumas formulações dos quilombolas verifiquem-se demandas por maiores adequações em matéria de infraestrutura, frequência e atuação extensionista e estabelecimento de canais de comercialização, entre outras, as representações sobre o projeto Ecoforte, mobilizadas por alguns deles, expressam avaliações positivas sobre o mesmo e as ações executadas, quando levados a refletir sobre os resultados do projeto. Assim, apontam resultados positivos ao grupo e à comunidade, permanecendo, contudo, uma influência da posição discursiva e condições de produção sempre operantes sob as determinações ideológicas que regem a discursividade dos sujeitos: "Eles trouxe muitas coisas, beneficiano pro nosso grupo, coisa que a gente não tinha e hoje a gente tem, como nossa cozinha completa [...]” (QE-1); "[...] trouxeram nossos equipamentos, que a gente era com dificuldade pra fazer as coisa. [...] aí ajudou bastante.” (QE-3); “[...] eles fizeram um plano de trabalho, [...] capacitaram o pessoal.... [...] temos pessoas fabricano os derivado da mandioca lá por conta própria [...] e vendeno aqui na fêra, e tá tendo resultado.” (QE-11).

Outro enunciado, formulado em resposta à mesma pergunta por locutora não participante dessas ações do Ecoforte, e que não procede a uma abordagem avaliativa do mesmo, mas sim responsabilizadora de um sucesso a ser alcançado, é expressivo de um sentimento local de que haja melhorias na comunidade para a manutenção e permanência de seus integrantes a partir das oportunidades geradas por ações dessa natureza: "Eu espero que dê certo, que eles trabalhe, pra sobrevivê, pra depois num [...] caí fora [...] pelo mundo aí afora!” (QE-10). Percebe-se um efeito parafrásico mobilizador de sentidos que atravessam os discursos, sendo verificados noutras enunciações acerca da própria Extensão Rural ("a extensão rural é justamente isso, é pra que você possa fazer um trabalho onde as pessoas possa ter condições de sobreviver lá [...] na sua comunidade... pra que [...] não precise sair de lá [...].” QE-11), convergentes com discursos institucionais igualmente atravessados por esse efeito de sentido de discurso fatalístico que objetiva o êxodo rural como fatalidade relacionada à falta de alternativas e condições necessárias à permanência quilombola:

Quando privados de sua territorialidade e, assim, alienados de seu modo tradicional de vida e produção, muitos quilombolas buscam o caminho das perife- 
rias das grandes cidades. Simultaneamente, a contínua mobilidade dos quilombolas para os centros urbanos, a longo prazo, resulta na dissolução de suas comunidades e de sua identidade. (Santos, [20--?], p. 5).

Embora por vezes as participantes do grupo das usuárias tenham buscado uma representação positiva dos objetos, as representações sobre o projeto Ecoforte nem sempre tiveram esse caráter otimista. Como evidência, verifica-se, por exemplo, a circunstância da desistência temporária de cinco usuárias, decorrente do desânimo inicial com as ações. Elas retornaram posteriormente, estimuladas pela chegada dos equipamentos para a atividade de beneficiamento, como ressaltou a participante QE-4. Verifica-se, novamente, como as ações dos sujeitos podem ser determinadas pelas suas representações sociais, de modo que no contexto do desenvolvimento das ações a inexistência de representações positivas capazes de orientar os indivíduos à sua participação nas mesmas pode levá-los ao distanciamento.

O desânimo com projetos e ações na comunidade torna-se um fato comum em Nova Jatobá, sendo frequentemente significado nos discursos gerais a partir de referências explícitas que representam os próprios moradores como desacreditados das ações, como se verificou mediante entrevistas informais e também no decorrer das observações e escutas realizadas durante a plenária assistida na Associação Quilombola.

Referindo-se especificamente ao grupo de usuárias do projeto Ecoforte, um dos extensionistas, TE-1, também ancora o sentido de desânimo do “outro" em seu papel de agente envolvido nas ações de desenvolvimento rural. Procedendo a deslocamentos de sentidos, por meio de discurso responsabilizador, ora o locutor atribui ao "outro" a razão de seu próprio desestímulo ("a gente sentiu essa [...] falta de interesse, pelo menos na pós-reunião! Na reunião se mostrava interessado e tudo, mas, quando saia, a prática deles não... não era [...] muito contínua, né. [...] Pode ser um grupo que não seja [...] animado pra aquele trabalho, aquele projeto.”), ora atribui a si mesmo, enunciando o próprio envolvimento incipiente nas ações direcionadas ("ou esse grupo precisa de um acompanhamento mais de perto, a gente tá num acompanhamento mais próximo pra ver se os resultados fica melhor - de repente eles podem diminuir porquê sentem, sei lá, falta de uma assessoria, de um acompanhamento, né”). Pelo discurso responsabilizador aqui mobilizado, busca-se um sentido de corresponsabilidade das ações, sendo ancorados e avaliados os papeis de ambos os extremos envolvidos na questão ${ }^{10}$.

Cabe observar que o extensionista também busca relacionar o desestímulo referente ao envolvimento em ações na comunidade à influência de questões operacionais ("Lá em Curaçá, [...] eles conseguem fluir bem quando a prefeitura consegue fechar os contratos com o PNAE com eles [...]. Mas depois, quando termina os contratos do PNAE, [...] a gente vê que os grupo começa a desanimar de novo, porque produz e não tem onde vender [...].”) e aspectos culturais da mesma, continuando, neste último caso, o ingresso numa formação discursiva da responsabilização do sujeito assistido:

E por outro lado é cultural, é... as comunidades já tão acostumadas numa prática cotidiana deles, de plantar e vender pra um atravessador [...]. [...] quando a gente tenta [...] fazer com que eles mesmo beneficie a produção deles pra agregar valor e vender esse produto no mercado, então o desafio é algo novo pra eles! Eles agora vão ter que se qualificar, né, precisar ter um trabalhinho a mais

\footnotetext{
${ }^{10}$ Como em outros enunciados, observe-se, ainda, a presença de típicas marcas linguístico-discursivas ("né”; "sei lá”) que, na forma como foram enunciadas, se estabelecem em cumprimento de algumas funções, como a finalização ou a interrupção do dizer ("não dizer"), que interdita um aprofundamento sobre aquilo que se discursa, além da pausa (...), que pela forma como fora enunciada marca um sentido de antecipação, com uma breve reflexão sobre o que pode e deve ser dito, como no trecho: "a prática deles não... não era uma prática muito contínua"; "Talvez precise mesmo é de uma... uma renovação no grupo" (TE-1).
} 
pra levar o produto até o mercado, e às vezes eles não estão disposto a isso! [...] Então quando eles não abraçam aquela causa aí não vai porque eles preferem ficar na mesma coisa que eles já faziam antes. (TE-1).

Essa postura atribuída aos comunitários em geral e que também já esteve relacionada a usuárias do projeto Ecoforte, também se torna expressiva de um contexto de silenciamento institucional no que tange a ações educativas e práticas de Extensão Rural que instiguem o desenvolvimento de potencialidades participativas, orientadas à definição de estratégias de superação dos entraves de ordem operacional, cultural e do próprio distanciamento da ação extensionista. A própria necessidade de um maior acompanhamento é objetivada pelo extensionista, a partir de enunciação em cujos sentidos atravessados se estabiliza também a caracterização das ações num aspecto técnico ("o nosso projeto ele é mais de estruturação, de organização, então era mais de estruturação dos equipamentos. Então o problema pode ser esse, a falta de um acompanhamento contínuo" TE-1). Como se verifica, tal enunciado estabelece sentidos contrastantes com o de outras formas enunciativas nas quais se busca uma afirmação da Extensão Rural no âmbito do referido projeto. Estas serão abordadas na próxima seção, que traz a análise dos discursos mobilizados pelos praticantes de ATER.

\section{REPRESENTAÇÕES SOCIAIS DOS EXTENSIONISTAS SOBRE A EXTENSÃO RURAL E IDENTIDADE ÉTNICA}

No outro extremo das relações discursivas abordadas, relacionam-se as representações e efeitos de sentidos constituídos mediante enunciações dos sujeitos praticantes, neste caso, dois agentes com considerável trajetória no serviço de ATER: TE-1, com 8 anos de experiência, tendo iniciado a carreira em outra entidade; TE-2, com 10 anos de experiência iniciada também em outro âmbito institucional. Nenhum com histórico de atuação em ATER específica para quilombolas, apesar de inseridos numa instituição de referência e que há sete anos desenvolve ações numa comunidade que expressa tal especificidade.

De maneira geral, os extensionistas conceituam o quilombo a partir da mobilização de alguns aspectos básicos de sua história no Brasil, mas sem buscar expressar uma contextualização mais profunda sobre a questão, o que, entretanto, não inviabiliza a constituição de sentidos através do discurso. No aspecto de um caráter genérico, destacam-se inclusive recursos discursivos que, na forma como empregadas, assumem a função de notáveis marcas de superficialidade no discurso, como constantes pausas (...), recursos alinhados à supressão/interdição do dizer (“né”, “mas é isso", etc.) e comparações vagas: "É... pegano... bom, o quilombo, entendo também como uma comunidade quilombola, né, é uma comunidade, como a gente chama de comunidade tradicional.” TE-1).

No processo de representação das identidades negra e quilombola, a ideia de conservação de aspectos socioculturais e de retomada de posição ante um contexto de prerrogativas legais (demonstrando-se, aí, algum nível de apropriação individual-coletiva sobre as relações de poder às quais estão envoltos esses grupos) são eleitas em meio às reservas da memória para figurar como símbolo de resistência no discurso dos extensionistas. Assim, apesar de um caráter genérico presente nas enunciações referidas, são ancorados alguns sentidos de resistência, como quando o quilombola é caracterizado como alguém: “[...] que durante todos esses séculos vem lutano pra ter direito a um espaço digno, né, uma vida digna.” (TE-2).

Isso se relaciona a padrões de apropriação sobre a questão quilombola, acerca da qual se torna discutível (no meio acadêmico, por exemplo) como o panorama das relaçóes sociais no Brasil inscrevem-se num contexto determinado pelos desdobramentos do sistema de domi- 
nação escravista, pelo que o segmento negro em geral e os quilombolas em particular lograram consequências negativas, sendo postos em via de acesso a direitos fundamentais. E o seu reposicionamento nesse campo de poder demandaria, dentre outros aspectos, a assunção de postura reivindicatória atrelada a processos de autoafirmação e de valorização de sua cultura e identidade, sendo a luta por direitos uma questão fundamental e que se põe no cerne de representações tanto do senso comum, quanto de abordagens científicas sobre o tema.

Referenciando o quilombo como "comunidade tradicional”, as enunciações de ambos os extensionistas mobilizam terminologia jurídica averbada por instrumentos legais normativos e comumente utilizada no contexto das políticas de desenvolvimento rural e das atuais chamadas públicas de ATER para se referir ao atendimento de diferentes grupos com identidade específica ou mesmo a um aspecto de transversalidade nas ações: “[...] eu entendo o quilombo como a nossas raízes, né, comunidades tradicionais que há muito, muito tempo vem tentando resistir [...]” (TE-1); "Quilombo pra mim é uma... uma comunidade tradicional, né... com pessoas, de... negras, né... da raça negra, e que ocuparam aquele espaço [...]” (TE-2). O referido termo é reproduzido pelos meios de comunicação, pelo discurso acadêmico-científico e por documentos técnico-institucionais e também transita no universo profissional dos extensionistas, ancorando-se no discurso sobre identidade étnica a partir da mobilização de elementos de um discurso legal-normativo e técnico-científico, ainda que desprovido de profundas reflexões sobre o contexto a que se mantém vinculado.

Nos enunciados convergentes de ambos os extensionistas verifica-se uma atribuição de responsabilidade, aos quilombolas, de assumirem sua própria identidade. Mas, ao fazê-lo de forma ainda mais categórica, TE-1 justifica o fato identificando o aspecto da resistência do sujeito referente quanto a essa afirmação identitária, lhe atribuindo também um caráter inercial: "Ser quilombola é assumir uma identidade, né, uma identidade... assumir as origens. [...] Porque, é... tem muitos quilombolas que não se assume: 'Eu sou quilombola!', né, não sei, por alguma questão ou outra... Mas é isso, [...] é assumir a identidade que vem é... herdano ao longo dos tempos". Embora aponte uma possibilidade de causa da "não afirmação", a deixa em suspenso, não expondo as explicações possíveis. O não dito (explicitado a partir do dito: "por alguma questão ou outra...”), e a forma como se enuncia o explicitamente negado ("não sei”), significam. Explicitam, antonimicamente, algum nível de cognição sobre aspectos relacionados à ideia objetivada, mas que não se teve a intenção de problematizar, de aprofundar no discurso.

Como se problematizou anteriormente, à assunção da identidade quilombola impor-se-ia o receio pela estigmatização oriunda dos efeitos do contexto intersubjetivo em que a constituição do "eu" se dá através de uma experiência alicerçada nas relações interpessoais com o "outro", podendo haver atitudes de aproximação ou resistência conforme o investimento em representações positivas ou negativas. Com algum nível de apropriação sobre isso, o "não dizer" acima referido, empreendido acerca de questões que interfiram na autoafirmação quilombola, irrompe atitude de antecipação acerca de sentidos apreendidos pelo extensionista como algo tacitamente estabelecido, ou seja, já compreendido, e que, assim sendo, não precisaria ser dito.

Nos enunciados que funcionam como paráfrase de um discurso base ao qual se orienta a formação discursiva sobre os sentidos atribuídos à identidade quilombola ("Ser quilombola é assumir uma identidade, [...] assumir as origens" TE-1; "reconhecer sua própria origem"; "ser quilombola é acima de tudo se reconhecer" TE-2), explicita-se uma ideia de assentimento da filiação étnico-racial, um efeito cuja antecipação o mostra/torna conveniente em meio ao contexto dado, sendo que esse mesmo sentido de afirmação da origem étnica também pode ser verificado na fala dos entrevistados da comunidade, no seu processo de busca pela legitimação da própria identidade socialmente construída. 
Em relação à atitude discursiva da extensionista (TE-2), no enunciado “[...] ser quilombola pra mim eu acredito que é, antes de tudo, reconhecer sua própria origem, né... de negro, de... que foi trazido [...] pra nosso país, né... de forma brutal e que durante todos esses séculos vem lutano pra ter direito a um espaço digno, né, uma vida digna.”, explicita sentidos relacionados ao aspecto da busca histórica do segmento pelo acesso a prerrogativas, enquanto um discurso histórico alinhado à formação discursiva da valorização identitária. Apoiando-se numa formação discursiva da vulnerabilidade socioeconômica, (re)produz também o efeito de sentido de uma desigualdade secular relacionada às relações sócioraciais e que, como se sabe, coloca a necessidade de acesso a recursos, serviços e condições sociais e econômicas indispensáveis a um bem viver para os povos quilombolas. Estes são alguns dos sentidos ancorados pelos extensionistas enquanto significativos dos modos de existência quilombola.

No processo de ancoragem de sentidos constituintes de sua compreensão acerca da figura institucional o discurso dos extensionistas buscam a manutenção de uma imagem positiva da entidade, como também se observou em boa parte das falas das quilombolas usuárias do projeto Ecoforte, nesse caso explicitando o aspecto do compromisso institucional, como no enunciado: “[...] a presença do IRPAA nessa comunidade já desde 2010, 2011, né. Então, quando a gente tem um projeto lá como o Ecoforte é a entidade que tá lá na comunidade, e aí onde a entidade tá, é... o trabalho do projeto Ecoforte é uma meta específica em ter que cumprir." (TE-1).

Observem-se que as enunciações de ambos os técnicos tendem a ser convergentes também quanto ao aspecto da produção de sentidos sobre si mesmos (enquanto agentes atuantes na comunidade), a partir de sua visão sobre o julgamento do "outro" nessa relação mediada pelas ações de ATER, colocando-se a favor daquelas versões que sejam mais positivas acerca dessa realidade que eles objetivam a partir de um discurso econômico e também de um discurso técnico-profissional que fundam suas formações ideológicas.

A partir dos elementos acionados pelos extensionistas para estabilização de representações acerca de como acham que são vistos pelos quilombolas, portanto, se constituem tais efeitos de sentidos, como nos enunciados: “[...] uma oportunidade de tá ajudano eles a crescerem, né, a desenvolver a produção, [...] a melhoria da renda" (TE-1); "A partir de uma assessoria técnica anterior [...] surgiu a possibilidade de ter uma unidade de beneficiamento [...] pra gerar renda e melhorar essas famílias" (TE-2), bem como o discurso técnico-profissional: "acho que eles nos vê tanto como assessoria - como entidade, como parceiros" (TE-2); "acredito que eles enxergam a gente como uma... uma parceria” (TE-1). Assim, tendem a objetivar elementos cujos sentidos ancorados se mostrem mais plausíveis e sejam mais aceitos. Estes sentidos podem inclusive ser compartilhados pelo "outro", havendo reflexos em seus enunciados produzidos em torno de outros aspectos relacionados à Extensão Rural ${ }^{11}$, sendo corroborada a ideia referida por Premebida e Almeida (2006, p. 461), em referência a Bourdieu (1974), sobre "compartilhamento" de "sistema simbólico" que referenda, a partir do alcance de consenso, os níveis de compreensão do objeto discursivo e sua própria aceitação pelos sujeitos envolvidos.

Em relação às representações sobre a Extensão Rural, pode se verificar como em dois enunciados específicos os extensionistas passam a objetivar as ações desenvolvidas no âmbito do projeto Ecoforte como sendo ações de Extensão Rural, ainda que em outros enunciados dispostos ao longo desse trabalho se encontrem contrastes. Assim, quando perguntados sobre

\footnotetext{
${ }^{11}$ Não obstante os quilombolas teçam representações a partir do próprio contexto, pode-se verificar algum nível de convergência de sentidos, como em enunciados representativos do discurso econômico, como: "Quando você tem [...] aqueles projeto que... vêm pra extensão rural pra pudê o pessoal crescê.” (QE-8); “[...] despertar o interesse das pessoas da comunidade pra que pudesse [...] fazer alguma coisa pra poder melhorar suas qualidade de vida e a sua renda familiar.", "pra que você possa fazer um trabalho onde as pessoas possa ter condições de sobreviver lá na sua terra" (QE-11); "Eu espero que dê certo, que eles trabalhe, pra sobrevivê [...]" (QE-10), entre outros enunciados que expressam convergência entre os dois grupos.
} 
tais objetos: "Sim, sim. O projeto Ecoforte uma de suas metas é a extensão rural, que é, além da estruturação dos equipamentos, o acompanhamento da equipe nessa comunidade durante os dois anos, né, que a gente chama de Assessoria Técnica e Extensão Rural, [...] com os grupos." (TE-1); e "Sim, porque o extensionista ele faz essa ponte, [...] entre as políticas públicas, as ações governamentais ou não, e as comunidades rurais. Então o extensionista ele tem que fazer o fluxo da ponte ser contínuo." (TE-2). Percebem-se nesses enunciados os aspectos do discurso técnico-profissional, o qual busca estabelecer uma afirmação do objeto em meio ao discurso. Esses enunciados serão retomados, mas já cabe aqui apontar aspectos da contradição, em que o sentido de afirmação de Extensão Rural vinculada ao projeto Ecoforte, intencionalmente estabelecido para tornar aceita a visão proposta sobre uma ligação entre os dois objetos, se choca com sentidos opostos, explicitados através de enunciados outros, como, por exemplo: "o nosso projeto ele é mais de estruturação, de organização, então era mais de estruturação dos equipamentos” (TE-1).

Convergindo com sentidos observados em enunciados formulados por alguns quilombolas, também TE-1 (re)produz enunciados que expressam a influência de um discurso econômico paralelo ao qual se procede a uma ancoragem da Extensão Rural enquanto ação interventora com algum nível de relação com o trabalho: “[...] extensão rural é um pouco disso que eu falei, né. Então [...] quando a gente vai lá tentar [...] estruturar aquela comunidade, melhorando o trabalho, [...] uma forma de fazer com que as pessoas que tão ali mais no meio rural também consigam, é... uma, uma qualificação também de trabalho [...].”. Assim, busca estabelecer um sentido positivo para a mesma, como também se observou em enunciados (re)produzidos por alguns quilombolas.

A enunciação de TE-2, traz uma representação da Extensão Rural enquanto um serviço fundamental para a transformação da realidade de grupos rurais: “[...] eu acho que extensão rural é você possibilitar a chegada de oportunidade, de conhecimento e outras informações, onde não se chega né... nos locais mais esquecidos, principalmente.” (TE-2). Neste e noutros enunciados, como: "onde deveria ter um médico, um assistente técnico, um agente de educação... chega o extensionista primeiro” (TE-2), o discurso mobilizado traz a objetivação de elementos demonstrativos de uma realidade de vulnerabilidade dos grupos rurais em geral. Estabelece sentidos condizentes com aqueles explicitados por discursos acadêmico-científicos e que também reverberam a identificação de um estado de negligência a grupos rurais em geral e grupos quilombolas em particular, destacando-se, por exemplo, quanto a este último caso, que "[...] a grande maioria destes espaços têm sido esquecidos do conjunto de serviços essenciais tais como saúde, moradia, transporte, educação e lazer.” (NUNES, 2015, p. 119) ${ }^{12}$.

$\mathrm{Na}$ formação discursiva de discurso técnico-profissional, tem-se o atravessamento do discurso responsabilizador, empreendido para (re)constituir um significado no modelo proposto de prática ideal, ancorando a responsabilidade profissional relacionada à Extensão Rural ao fazer extensionista: "o extensionista faz um papel muito mais do que uma assessoria técnica, que vai numa comunidade levar uma tecnologia” (TE-2). Noutro enunciado já anteriormente abordado também se explicitam semelhantes relações paráfrasicas e efeitos de sentidos: “a extensão rural, que é, além da estruturação dos equipamentos, o acompanhamento [...] durante os dois anos” (TE-1). Tem-se aqui inclusive uma prática discursiva autorreferente, explicitan-

\footnotetext{
${ }^{12}$ Isso não destoa do verificado na comunidade Nova Jatobá, pois embora haja avanços em alguns âmbitos, como acesso a algumas ações e um equipamento público de educação, outras áreas esperam atenção. Há, por exemplo, esforços através da Associação Quilombola quanto à viabilização de serviços de saúde mais significativos, como a presença periódica de equipe de saúde no espaço de uma das duas escolas menores desativas, mas este continua como um feito a se alcançar. O acesso a serviços de saúde se concretiza no município de Curaçá. Na comunidade há apenas o acompanhamento por três Agentes Comunitárias de Saúde em três dos sete povoados, não havendo uma atuação regular em todos estes, conforme relatos.
} 
do-se a própria responsabilidade do locutor enquanto técnico de ATER, mesmo que se estabeleça uma impessoalidade no discurso.

Os enunciados supracitados buscam intersecção com sentidos estabilizados pelo discurso acadêmico-científico, que caracteriza a Extensão Rural como mais abrangente em relação à assistência técnica. Verifica-se naqueles a influência de recursos parafrásicos e a busca pela ancoragem de sentidos mais aceitos nas discussões sobre Extensão Rural, apresentando-se como mais condizentes com as novas determinações das ações de ATER. Seus locutores fundamentam-se na leitura do próprio contexto atual em que se inserem, no qual se impõe a necessidade de perceber as singularidades da Assistência Técnica e da Extensão Rural, esta cujas ações obedecem a um maior período (embora temporário, dois anos, no modelo vigente) em detrimento da primeira, que é momentânea e possui caráter emergencial. Apesar das limitações quanto ao tempo, entre outras criticadas pela literatura, a atual PNATER (Lei $n^{0} 12.188 / 2010$ ) estabelece a Extensão Rural enquanto um processo contínuo de educação que propicie um modelo de desenvolvimento rural sustentável, o que, entretanto, requer do extensionista uma postura inovadora para uma adequada prestação do serviço. Esse aspecto era defendido desde Paulo Freire (1983), que propõe a dialogicidade e o respeito às formas de conhecimento popular a ser envolvidas no processo, o que não tem encontrado espaço na simples assistência técnica, tampouco numa Extensão Rural não dialógica.

Ainda que haja um sentido de afirmação da Extensão Rural, mobilizado por meio de um discurso técnico-profissional e responsabilizador, conforme observado, pela influência polissêmica as produções discursivas de ambos extensionistas também trazem enunciados que permitem apreender, por outro lado, um sentido de ação unidirecional, de fora para dentro (“quando a gente leva acesso das políticas públicas até as comunidade”, "quando a gente vai lá tentar melho...", "quando a gente leva eles pra acessarem políticas públicas como PNAE” TE-1; “o extensionista [...] leva uma informação" TE-2), o que pode ir exatamente de encontro aos princípios de dialogicidade, à medida que não valorize a capacidade participativa e o conhecimento do outro. Desse modo, associando a Extensão Rural ao seu ambiente familiar, no qual assumem o lugar de profissionais executores das ações, os extensionistas caracterizam a si mesmos com autoridade de "poder" e de "saber", caracterizando também o "outro" como público beneficiário do processo que executam. A partir dessas enunciações, inscritas num discurso profissional vinculado a uma formação discursiva da intervenção assistencialista, o sujeito outro, relacionado em função do objeto referente, não figura plenamente envolvido no processo, sendo representado sobremaneira como simples foco de intervenções vindas de fora.

Tais enunciados produzidos pelos extensionistas expressam relações parafrásicas que vão dando sentido ao dizível, em seu funcionamento enquanto paráfrase de discursos base, como, por exemplo, aquele estabelecido por meio do enunciado: “o extensionista ele faz essa ponte, [...] ele tem que fazer o fluxo da ponte ser contínuo.” (TE-2). Assim, a relação parafrásica e de sentido estabelecida por outros enunciados que a este se filiam ("a gente leva"; "a gente vai" TE-1; “o extensionista [...] leva” TE-2) expressa um efeito cognitivo sob o qual os sujeitos têm em conta, em meio ao processo de explicação e significação do objeto, a própria primazia na execução dos serviços. Nesse contexto, o curso de ação (“fluxo da ponte”) se expressa de modo unilateral, e o sujeito “outro" é representado ao fim, e não sobre o mesmo.

Partindo-se de fragmento discursivo de um dos extensionistas, analisa-se como uma instituição prestadora pode valer-se da existência de uma identidade quilombola e mesmo da perspectiva de gênero no momento de concorrer às chamadas públicas, ainda que no processo de desenvolvimento dos trabalhos tal aspecto identitário não seja considerado, sendo apenas um critério participativo que favorece um aumento na pontuação durante a concorrência: 
O próprio projeto Ecoforte, quando ele saiu para a gente elaborar, ele tinha lá que o projeto ele era pra agricultores familiares, tal, mas que ia contar ponto, na elaboração desse projeto, projetos que apresentasse também que ia beneficiar mulheres, grupos de mulheres... que ia beneficiar comunidades quilombolas, né. E aí como agente já tem um histórico de acompanhamento dessa comunidade com outros projetos a gente colocou a comunidade Jatobá! E por ser quilombola ela ajuda nós a pontuar no Ecoforte! Mas não pra dizer que o projeto ele foi exclusivo pra quilombola, ele foi geral! Mas o fato de ter a comunidade quilombola entre as comunidades que seriam acompanhadas, a gente teve uma pontuação a mais, comparando com outras organizações, se a gente não tivesse colocado eles! Mas a gente colocou principalmente porque a gente já vinha acompanhando! E aí o fato de ser quilombola ajudou a somar pontos. Mas o trabalho foi de igual para todo mundo! (TE-1).

Torna-se, assim, problematizável o lugar que é dado a estes segmentos específicos nas propostas de desenvolvimento rural. Se por um lado há promoção do seu ingresso, por outro não há maiores determinações de atenção às suas especificidades pós-inclusão, subentendendo-se que somente a inserção em políticas e ações de caráter universalista bastaria à perspectiva de desenvolvimento, muito embora os resultados possam se manter distantes do mesmo etnodesenvolvimento tão referido em discursos oficiais e normativos.

Ocorre, portanto, um silenciamento desde a estrutura operacional mais ampla (política $>$ plano $>$ programa $>$ projeto) e que se reverbera no próprio desenvolvimento do serviço, de modo que, não dispondo de parâmetros mais bem definidos nos quais possam se basear, os praticantes, já influenciados por contextos tradicionais de ação, empreendem também um silenciamento. E estes têm como respaldo a própria noção de que devem existir outras ações mais específicas para o segmento em questão, devendo ser delas a missão de observância quanto às especificidades sócio-étnico-raciais.

Sobre a indagação se existe diferença entre ATER quilombola e ATER para agricultores em geral, enunciado produzido pela extensionista explicita alguns efeitos de sentidos que o significam a partir de elementos constitutivos de uma especificidade quilombola relacionável a uma necessidade de atenção específica, textualizado no fragmento: "Sim, as comunidades quilombolas têm necessidades culturais específicas, por todos os anos de negação de direitos" (TE2), embora não tenha aprofundado essa discussão.

Uma fragilidade na apropriação discursiva sobre a especificidade da Extensão Rural quilombola torna-se mais apreensível a partir de enunciados formulados pelo extensionista TE-1, corroborando aspectos também apontados em contexto analisado por Santos (2014). No enunciado exposto a seguir, verificam-se inclusive referências explícitas a uma falta de conhecimento sobre a questão:

Rapaz... é... eu não sei de fato assim! Na prática eu não sei lhe dizer se tem diferença, né. O que existe é... por nunca ter atuado em ATER quilombola, então eu não sei lhe dizer se existe diferença. Porque assim, o que de fato existe de diferença é: quando sai as chamadas públicas, projeto de ATER, então quando ele é quilombola ele vai concorrer só pra entre os concorrentes quilombola. E o outro é... geral, ele é pra geral, ele não é específico. Mas de como ele acontece, a diferença eu não sei lhe dizer não! (TE-1).

Acerca da participação em formações sobre as questões étnico-raciais no âmbito da instituição, TE-2 repete um não ingresso no jogo de sentidos, pois não formulou nenhuma resposta. Já TE-1, perguntado sobre a participação em alguma formação sobre questões étnico-raciais, expôs versão dos fatos pela qual se explicita a reserva de um tratamento periférico ao 
tema, enquanto subsumido a outras questões a partir de uma tradicional perspectiva de homogeneidade e transversalidade:

Já! É... o IRPAA sempre... já tem uns três anos, o IRPAA vem promoveno debates na equipe, falando sobre gênero. Então são debates, é... só com mulheres, debates só com homens, hora encontros mistos, debatendo a questão de gênero, específica. E dentro da questão de gênero surge essa questão também da desigualdade social, racial. É uma das questões debatidas nos encontros de gênero também! É uma política da instituição esse trabalho com a equipe. (TE-1).

Cabe observar que mesmo que não se expresse uma profundidade em enunciados que organizam formações discursivas (re)construídas na luta por direitos diferenciados, esses agentes integram esse campo e o influenciam ao constituir uma relação com o sujeito outro (os quilombolas: usuários, espectadores), constituindo-se também sujeitos (extensionistas: profissionais, executores).

\section{CONSIDERAÇÕES FINAIS}

A partir deste estudo se verificou a ocorrência de diferentes movimentos de sentidos em torno da Extensão Rural e em meio à realidade de sujeitos em diferentes posições num contexto de ações de desenvolvimento rural em comunidade de identidade específica.

A partir das produções discursivas examinadas constataram-se aproximações e divergências entre os dois grupos e que se relacionam tanto à influência da característica polissêmica do discurso, quanto à necessidade de consenso coletivo sobre dados objetos. Assim, puderam ser verificados atravessamentos, antecipações, silenciamentos e contradições cujos sentidos constituídos assumem seu funcionamento sócio-histórico-ideológico a partir da atitude discursiva dos sujeitos.

Conforme a Teoria das Representações Sociais, é comum que no processo de interpretação e significação o sujeito processe uma classificação do objeto partindo de imagens mais familiares ao seu contexto. Em sendo o universo da Extensão Rural algo que soa estranho, a priori, aos sujeitos quilombolas, os mesmos a aproximam (ancoram) e a categorizam (objetivam) buscando a sua familiarização. Neste sentido, como se pode verificar as ideias de "união" e "trabalho", por exemplo, constituem o imaginário e são mobilizadas no discurso por muitos quilombolas, havendo uma tendência de aproximação do trabalho de ATER com os valores grupais e aspectos coletivos da comunidade.

Os elementos "união" e "trabalho" foram igualmente mobilizados em meio às categorias fundantes no discurso para representação da identidade quilombola por alguns sujeitos, embora a objetivação de outras categorias também tenha ocorrido, a exemplo de elementos histórico-socioculturais acionados para representação dessa mesma identidade a partir do discurso histórico, constituindo-a como um fato social e psíquico.

A união constitui o imaginário discursivo de quilombolas e foi acionada no processo de representação dos objetos propostos, num processo de objetivação e ancoragem em que sua posição discursiva recorre ao sentido comunitário e de trabalho coletivo enquanto um sentido mais familiar e que se torna estruturante das suas representações sociais. A união figura na memória em relação aos antigos laços de solidariedade testemunhados pelo discurso. Torna-se enunciável mediante o resgate do sentido de coletividade constituinte do universo simbólico inerente à vida em comunidade e trabalho coletivo, sendo este sentido de unidade e de trabalho coletivo incorporado aos objetos propostos, como a Extensão Rural, as ações de desenvol- 
vimento rural executadas na comunidade e principalmente a identidade quilombola. Esse aspecto é notável, ainda que dada valorização do trabalho coletivo também possa, em certos casos, ser fruto de um reconhecimento externo desse elemento enquanto característico de comunidades quilombolas, ressurgindo em enunciados atravessados por formações discursivas (re) construídas no contexto de luta por direitos.

Por vezes, quando objetivam a Extensão Rural a partir de sua relação como o trabalho, caracterizando-a mediante um aspecto prático e utilitarista, os quilombolas traçam a sua significação a partir de relação afetiva com a questão da própria sobrevivência e reprodução socioeconômica, sendo o discurso econômico espelhado em algumas formulações dos sujeitos executores, convergência expressiva do estabelecimento de níveis de consenso coletivo.

Muitas vezes a Extensão Rural também passa a ser apontada como um conjunto de ações vindas de fora, do governo ou de instituições. É assim representada a partir de um sentido assistencial associado a entidades externas incumbidas de "levar" a mudança ("melhorias") à comunidade. Mas essas fórmulas explicativas filiam-se, muitas vezes, a sentidos que tradicionalmente se relacionam a uma influência de processos de difusão e de transferência de tecnologia e informação de maneira fundamentalmente orientada por princípios mais convencionais do que se poderia imaginar.

No que se refere à reprodução das mais recentes ações de desenvolvimento rural através do IRPAA na comunidade Nova Jatobá, evidenciaram-se representações indicativas de certa relação de dependência técnica do grupo atendido, podendo ser apreendidas a partir da explicitação de sentidos na enunciação empreendida por alguns quilombolas, e as quis também são corroborados pelas observações realizadas. Com efeito, alguns enunciados explicitam como a autonomia das usuárias do Ecoforte fica muitas vezes limitada a necessidades inerentes ao aspecto de fabricação dos produtos e ao processo de comercialização e gestão do negócio, além da necessidade de treinamento para operar os equipamentos, ação que ainda era aguardada pelas assistidas mesmo quando o projeto já estava em fase de finalização na comunidade.

Acerca do acima exposto, algumas enunciações dos próprios praticantes também explicitam sentidos correlatos a partir do atravessamento das significações, quando ancoram a realidade mediante discurso técnico-profissional atravessado pelo sentido de discurso de autoridade e inscrito numa formação ideológica de quem ocupa a posição de agente condutor das ações, seu lugar de fala.

Explicitam-se representações afins em enunciações empreendidas por um dos sujeitos quilombolas detentores de trajetória politico-representativa e que, por meio da composição das formações ideológicas em que se inscreve, ocorrem de forma mais categórica, ainda que alguns dos enunciados explicitem sua filiação a uma mesma formação discursiva de valorização institucional, como ocorre com as então usuárias do projeto Ecoforte. Verifica-se, assim, como o dizer e o dizível passam a ser determinados pelos lugares sociais, havendo em relação a este sujeito formulações de discurso mais irrestrito no potencial avaliativo do trabalho extensionista, enquanto recursos de antecipação e silenciamento foram mais influentes em discursos sob efeito do vínculo relacional.

Uma busca pela manutenção de sentidos mais positivos sobre a atuação institucional e extensionista é constatada tanto em relação às usuárias, quanto aos praticantes das ações de desenvolvimento. Apenas às vezes sentidos diversos, acerca do acompanhamento prestado, vem a ser explicitados em enunciações empreendidas por aquelas, inclinando-se a uma intensificação em enunciados (re)produzidos por sujeitos espectadores. Contudo, os sentidos do não dito permanecem atravessados nos discursos. 
Por vezes os sujeitos quilombolas procedem a uma maior profundidade reflexivo-argumentativa acerca da identidade étnica. Em muitas das enunciações que mobilizam verifica-se também a cessão do lugar de locutor ao interlocutor referido no discurso, com a citação de fala direta em forma de exemplificação ou explicação do já dito (meta enunciação), buscando fixar o entendimento e legitimar o dizer e as representações e sentidos ancorados. Em relação aos extensionistas, esses recursos quase nunca foram constatados.

As marcas de superficialidade reflexiva verificadas no discurso empreendido pelos extensionistas acerca da identidade quilombola exprimem uma dificuldade de explicitar uma postura mais engajada enquanto profissional inserido no contexto de uma comunidade rural com tal identidade específica, ainda que tenham buscado estabelecer, a partir de algumas enunciações, sentidos de compromisso institucional para com a comunidade e de discernimento sobre o papel do extensionista, o que aponta para a influência da contradição no funcionamento discursivo.

Mesmo tendo buscado relacionar as ações desenvolvidas no projeto Ecoforte com a Extensão Rural, buscando também diferenciar esta da assistência técnica, a significação mais ampla de enunciações produzidas pelos extensionistas inscrevem-nas em um plano mais relacionado a ações emergenciais e ao aspecto da assistência técnica, o que também ocorre com algumas enunciações produzidas pelas usuárias e por alguns espectadores dessas ações mais recentes na comunidade.

Sendo de natureza mais restrita a prática significada, constata-se uma dissonância em alguns discursos. $\mathrm{Na}$ execução do projeto Ecoforte as práticas assistivas se orientaram mais à resolução de problemas pontuais e efetivamente relacionados à transmissão de conhecimentos específicos, à transferência de equipamentos, sobretudo, e à necessidade de treinamento para sua utilização, entre outros aspectos inter-relacionados como necessidades mais prementes no direcionamento das ações para geração de trabalho e renda no âmbito rural.

No contexto do referido projeto que compreendeu o biênio 2016-2017, especificamente, as ações se desenvolveram sem muita relação com princípios mais gerais de educação e de formação cidadã, que têm se tornado mais defensáveis à prática da Extensão Rural e às ações com populações rurais. Por meio da Extensão Rural haveria, por exemplo, maiores possibilidades de articulação das ações desenvolvidas com questões de gênero e questões étnico-raciais, que estão no cerne da identidade individual e coletiva das usuárias desse projeto específico em Nova Jatobá, tratando-se de um grupo constituído por mulheres e que se auto afirmam quilombolas. A lei de ATER, inclusive, estabelece os aspectos de "gênero, geração, raça e etnia" (BRASIL, 2010) dentre os princípios que devem nortear as ações. Como verificado, as próprias ações de desenvolvimento executadas em Nova Jatobá inscrevem-se no âmbito de relações de poder, e a existência de tensionamentos internos (à associação, à comunidade, e ao próprio grupo de usuárias, etc.), também aponta a importância de uma atenção mais geral e que compreenda as questões sociais, em consonância ao apoio técnico às atividades produtivas.

Nesse contraste da busca pela ancoragem das ações do projeto Ecoforte numa relação com a Extensão Rural, em cujos direcionamentos mais recentes requerem a valorização dos aspectos socioculturais dos atendidos, torna-se verificável uma incipiente apropriação dos extensionistas sobre os aspectos relacionadas à identidade da comunidade e do segmento quilombola em geral, embora isso não signifique a inexistência de representações e efeitos de sentidos nas produções discursivas que (re)formulam. Num sentido geral, esse fato aponta uma fragilidade inerente à própria chamada pública, desprovida de maiores determinações acerca dos grupos a serem atendidos e suas especificidades. A admissibilidade de se considerar as especificidades dos atendidos torna-se evidente a partir da própria observação do modo como tais questões estruturam as relações sociais. 
Conforme verificado também se apresentam representações por meio de uma visão que ultrapassa uma noção de "neutralidade racial", explicitando, assim, uma influência do paradigma racial sob a interação entre sujeitos e seus modos de consideração da identidade étnico-racial, a qual, neste caso é mediada pelo discurso seja no conjunto das relações mais amplas com sujeitos do entorno, seja no contexto mais restrito das próprias ações de desenvolvimento rural. Isso aponta para a possibilidade de questões sociais mais gerais influírem nos processos de implementação dessas ações em contextos específicos, sendo a questão racial um elemento estruturante das relações no contexto sociocultural tanto urbano quanto rural. Portanto, a necessidade de atenção aos aspectos socioculturais e identitários de um grupo em meio às ações de desenvolvimento rural com ele desempenhadas impõe-se como princípio fundamental para o tão postulado etnodesenvolvimento.

Em suma, a produção de representações ante a necessidade de familiarização do não familiar e o modo como os sujeitos interagem entre si influenciam no trabalho de ATER, podendo, portanto, determinar o resultado dessas ações nesse contexto de múltiplas identidades: comunidade rural, quilombola e que tem a possibilidade de formação de grupos de trabalho tão mais específicos, como o grupo de mulheres observado. E nesse âmbito, a partir da construção de um universo familiar se processa a busca pela compreensão, explicação e significação da realidade.

\section{REFERÊNCIAS}

BRASIL. Lei ${ }^{\circ}$ 12.188, de 11 de janeiro de 2010. Institui a Política Nacional de Assistência Técnica e Extensão Rural para a Agricultura Familiar e Reforma Agrária - PNATER e o Programa Nacional de Assistência Técnica e Extensão Rural na Agricultura Familiar e na Reforma Agrária - PRONATER, altera a Lei $n^{\circ}$ 8.666, de 21 de junho de 1993, e dá outras providências. Disponível em: $<$ http://www.planalto.gov.br/ccivil_03/_Ato2007-2010/2010/Lei/L12188.htm>. Acesso em: 05 fev. 2018.

CAPORAL, F. R. Lei de Ater: exclusão da Agroecologia e outras armadilhas. Revista Agroecologia e Desenvolvimento Rural Sustentável, v. 4, n. 1, set./dez., 2011, p.23-33. Porto Alegre: EMATER-RS-ASCAR, 2011. Disponível em:<http://www.emater.tche.br/site/arquivos_pdf/teses/R-Agroec12-11_05_ Opiniao-Lei_ATER.pdf >. Acesso em: 15 fev. 2018.

DURKHEIM, É. As regras do método sociológico. Trad.: NEVES, P.; Rev.: BRANDÃO, E. 3. ed., São Paulo: Martins Fontes, 2007.

DURKHEIM, É. Da divisão do trabalho social. Trad.: BRANDÃ, E. 2. ed., São Paulo: Martins Fontes, 1999.

FOUCAULT, M. A arqueologia do saber. Trad.: NEVES, L. F. B. 7. ed., Rio de Janeiro: Forense Universitária, 2008.

FREIRE, P. Extensão ou Comunicação? 8. ed. Rio de Janeiro: Paz e Terra, 1983.

JODELET, D. “Representações sociais: um domínio em expansão”. In: JODELET, D. (Org.). As representações sociais. Rio de Ja $\neg$ neiro: UERJ, 2001.

JOVCHELOVITCH, S. Psicologia social, saber, comunidade e cultura. Psicologia \& Sociedade, v.16, n. 2, p. 20-31, maio/ago., 2004.

MENDES, J. F. A. Etnodesenvolvimento, assistência técnica e extensão rural: o caso do quilombo de Monte Alegre - Cachoeira do Itapemirim-ES. Dissertação (Mestrado em Desenvolvimento Territorial e Políticas Públicas) - Universidade Federal Rural do Rio de Janeiro, Seropédica, 2014.

MOSCOVICI, S. Representações sociais: investigação em psicologia social. 2. ed., Petrópolis, RJ: Vozes, 2003. 
NUNES, G. H. L. Educação escolar quilombola: processos de constituição e algumas experiências. Revista da ABPN, v. 8, n. 18, nov. 2015/fev. 2016, p.107-131.

ORLANDI, E. P. Análise de Discurso: princípios e procedimentos. Campinas, SP: Pontes, 6. ed., 2005 a.

ORLANDI, E. P. As formas do silêncio: no movimento dos sentidos. 6. ed., Campinas, SP: Unicamp, 2007.

ORLANDI, E. P. Michel Pêcheux e a Análise de Discurso. Estudos da língua(gem), n. 1, p. 9-13, 2005 b. Disponível em:< http://www.estudosdalinguagem.org/index.php/estudosdalinguagem/article/viewFile $/ 4 / 3>$. Acesso em: 10 fev. 2018.

PÊCHEUX, M. O discurso: estrutura ou acontecimento. Trad.: ORLANDI, E. P. Campinas, SP: Pontes, 1990.

PREMEBIDA, A.; ALMEIDA, J. Desenvolvimento rural e biopoder: reflexões a partir do campo tecnocientífico. Sociedade e Estado, Brasília, v. 21, n. 2, p. 459-486, maio/ago., 2006.

SANTOS, I. de J. As representações sociais dos quilombolas sobre a extensão rural na Comunidade Remanescente de Quilombo Lage dos Negros em Campo Formoso-Bahia. Dissertação (Mestrado em Extensão Rural e Desenvolvimento Local) - Universidade Federal Rural de Pernambuco, Recife, 2014.

SANTOS, I. de J.; ALMEIDA; M. das G. A. A. de. As representações sociais dos quilombolas sobre a extensão rural na Comunidade Remanescente de Quilombo Lage dos Negros em Campo Formoso-Bahia. Revista de Extensão e Estudos Rurais, v. 3, n. 1, p. 155-189, 2014. 